\title{
Perbandingan Peningkatan Kadar Malondialdehid (MDA) Serum setelah Olahraga Pagi dan Malam Hari pada Orang Tidak Terlatih
}

\author{
Mushab $^{1}$, Hairrudin ${ }^{2 *}$, Cholis Abrori ${ }^{3}$
}

\begin{abstract}
Abstrak
Olahraga mampu meningkatkan kadar radikal bebas dalam tubuh melalui beberapa mekanisme yaitu peningkatan aktivitas mitokondria, NADPH, dan XO serta inflamasi pada sel otot rangka yang mengakibatkan stimulasi aktivitas fagosit. Olahraga yang dilakukan pada malam hari memiliki beberapa mekanisme tambahan sehingga berpotensi menyebabkan peningkatan kadar radikal bebas lebih tinggi, yaitu faktor pencetus radikal bebas yang meningkat pada malam hari. Salah satu indikator untuk mengetahui kadar radikal bebas dalam tubuh yaitu malondialdehid (MDA). Tujuan: Menentukan perbandingan antara peningkatan kadar MDA serum setelah olahraga pada dan malam hari pada orang tidak terlatih. Penelitian ini merupakan uji klinis dengan pre dan post-test group design. Metode: Sampel berjumlah 20 mahasiswa Fakultas Kedokteran Universitas Jember yang tidak terlatih, masing-masing berperan ganda sebagai kelompok pagi (Kp) dan kelompok malam $(\mathrm{Km})$ sehingga jumlah total sampel sebesar 40. Olahraga yang dilakukan berupa sepeda statis dengan intensitas 70-80\% dari heart rate maksimal. Setelah satu minggu dilakukan croosing-over, yaitu sampel Kp dijadikan $\mathrm{Km}$ begitu pula sebaliknya. Pengukuran kadar MDA dilakukan sebelum dan setelah olahraga menggunakan metode TBARS. Peningkatan kadar MDA merupakan selisih dari kadar MDA setelah dan sebelum olahraga. Hasil: Peningkatan kadar MDA setelah olahraga pada pagi dan malam hari adalah $0,29 \pm 0,87 \mathrm{nmol} / \mathrm{mL}$ dan $1,13 \pm 1,2 \mathrm{nmol} / \mathrm{mL}$. Hasil uji statistik menunjukkan ada perbedaan yang signifikan $p=0,021 \quad(p<0,05)$. Simpulan: Peningkatan kadar MDA setelah olahraga pada malam hari lebih tinggi dibandingkan dengan peningkatan kadar MDA setelah olahraga pada pagi hari pada orang yang tidak terlatih.
\end{abstract}

Kata kunci: malondialdehid, olahraga, radikal bebas, TBARS

\begin{abstract}
Exercise can increase levels of free radicals in the body through several mechanisms, namely increased mitochondrial, NADPH, and XO activity, and inflammation of skeletal muscle cells that cause phagocytic activity. Exercise at night has several additional mechanisms that potentially causes higher levels of free radicals, namely free radical triggers that increase at night. One indicator to determine levels of free radicals in the body is malondialdehyde (MDA). Objectives: To determined the comparison between increased serum MDA levels after exercise in the morning and night in untrained people. Methods: This research was a clinical trial with pre and post-test group designs. The sample was 20 untrained medical students of Universitas Jember, each with a double role as the morning and night groups so that the total sample was 40 . The exercise carried out in the form of a static bicycle with an intensity of $70-80 \%$ of the maximum heart rate. After one week of crossing over, the Kp sample was made as $\mathrm{Km}$ and vice versa. MDA levels are measured before and after exercise using the TBARS method. Results: An increase in MDA levels after exercise in the morning and the night were $0.29 \pm 0.87 \mathrm{nmol} / \mathrm{mL}$ and $1.13 \pm 1.2 \mathrm{nmol} / \mathrm{mL}$. Statistical test results showed that there was a significant difference $p=0.021 \quad(p<0,05)$. Conclusion: The increase in MDA levels after exercise at night is higher than after exercise in the morning in untrained people.
\end{abstract}

Keywords: exercise, free radical, malondialdehyde, TBARS 
Affiliasi penulis: ${ }^{1}$ Pendidikan Dokter , Fakultas Kedokteran, Universitas Jember, Indonesia. ${ }^{2}$ Laboratorium Biokimia, Fakultas Kedokteran, Universitas Jember. Indonesia. ${ }^{3}$ Laboratorium Farmakologi, Fakultas Kedokteran, Universitas Jember. Indonesia. Korespondensi: Hairrudin. Email : hairrudin.fk@unej.ac.id. Telp: 08123200364

\section{PENDAHULUAN}

Masyarakat saat ini mulai memahami pentingnya olahraga. Hal ini dikarenakan perubahan gaya hidup yang menuntut masyarakat memiliki fisik dan tubuh yang prima untuk melakukan aktivitas sehari-hari. Sebagian besar masyarakat tidak memiliki waktu senggang yang cukup untuk melakukan olahraga. Sebagian dari mereka berolahraga pada malam hari dikarenakan pada pagi hari harus bekerja. Olahraga secara umum merupakan stresor fisiologis yang mampu merangsang hipotalamus memproduksi Corticotrophine Releasing Hormone $(\mathrm{CRH})$ sehingga menstumulasi hipofisis anterior menghasilkan Adreno Cortico Trophic Hormone (ACTH) yang kemudian mempengaruhi korteks untuk menghasilkan hormon stres yaitu kortisol. ${ }^{1}$ Kortisol mampu menyebabkan peningkatan radikal bebas. ${ }^{2}$ Radikal bebas adalah suatu molekul atau atom yang memiliki satu atau lebih elektron tidak berpasangan pada orbitnya sehingga bersifat reaktif. ${ }^{3}$ Olahraga pada malam hari mampu meningkatkan produksi hormon adrenalin yang berdampak pada peningkatan denyut jantung dan temperatur tubuh, sehingga membuat seseorang mengalami kesulitan memulai tidur. Kacaunya waktu tidur atau disebut dengan istilah gangguan ritme sirkadian mempengaruhi kadar radikal bebas dalam tubuh. Proses peningkatan pembentukan radikal bebas akibat gangguan ritme sirkadian dipengaruhi penurunan kadar melatonin dalam tubuh dan aktivitasnya sebagai antioksidan. ${ }^{4}$ Salah satu senyawa yang digunakan untuk menunjukkan adanya peningkatan radikal bebas di dalam tubuh adalah malondialdehid (MDA). ${ }^{5}$ Tujuan penelitian ini adalah untuk mengetahui perbandingan peningkatan kadar MDA serum setelah olahraga pagi dan malam hari pada orang tidak terlatih. Manfaat yang diharapkan dari hasil penelitian ini adalah memberikan rekomendasi tentang pemilihan waktu yang lebih tepat untuk melakukan olahraga terutama bagi orang yang tidak terlatih.

\section{METODE}

Jenis penelitian yang dilakukan adalah uji klinis dengan pre and post-test group design. Penelitian dilaksanakan pada bulan Februari 2020 di Fakultas Kedokteran Universitas Jember. Sukarelawan (sampel) terdiri dari 20 orang mahasiswa Fakultas Kedokteran Universitas Jember. Sampel dibagi menjadi 2 kelompok pemeriksaan yaitu: kelompok pagi (Kp) dan kelompok malam (Km). Prosedur olahraga yang dipilih berupa sepeda statis selama minimal 10 menit dan/atau mencapai target heart rate. Target heart rate pada penelitian ini menggunakan rumus persentase intensitas olahraga dikalikan denyut jantung maksimal. Denyut jantung maksimal tergantung dari umur sukarelawan (220-umur). ${ }^{6}$ Pengukuran kadar MDA serum dilakukan sebelum dan setelah olahraga menggunakan metode TBARS. Peningkatan kadar MDA merupakan selisih antara kadar MDA setelah dan sebelum olahraga. Tahap selanjutnya, sukarelawan di washing-out selama tujuh hari, kemudian dilakukan pindah silang (crossingover). Kelompok pemeriksaan pada pagi hari dijadikan kelompok pemeriksaan pada malam hari dan kelompok pemeriksaan malam hari dijadikan kelompok pemeriksaan pada pagi hari, sehingga didapatkan sampel untuk masing-masing kelompok sebanyak 20 orang dengan total sampel sebanyak 40 orang

Analisis statistik yang digunakan adalah uji normalitas saphiro-wilk yang dilanjutkan dengan uji $\mathrm{t}$ berpasangan (paired $t$ test) dan uji t dua kelompok bebas (two sample independent t test).

Penelitian ini dilakukan setelah mendapat persetujuan dari Komite Etik Penelitian Kesehatan Fakultas Kedokteran Universitas Jember Nomor: 1.386/H25.1.11/KE/2020.

\section{HASIL}

Sukarelawan dalam penelitian ini tergolong dalam kelompok usia remaja akhir. Usia sukarelawan tertua pada penelitian ini berusia 23 tahun dan yang termuda berusia 19 tahun. Rata-rata usia dari sukarelawan ini sebesar 20 tahun 6 bulan. Menurut Liguori et al (2018), usia memiliki peranan penting dalam pembentukan radikal bebas. Hal ini disebabkan oleh proses adaptasi tubuh dalam pembentukan 
antioksidan endogen. Selain itu pada usia tua rentan terjadi proses inflamasi yang berpengaruh dalam peningkatan kadar radikal bebas dalam tubuh. ${ }^{7}$

Rerata BMI (Body Mass Index) dalam penelitian ini yaitu sebesar $21,48 \mathrm{~kg} / \mathrm{m}^{2}$. Angka ini menunjukan bahwa rerata sukarelawan yang mengikuti penelitian ini termasuk kategori BMl normal $\left(18,5-24,9 \mathrm{~kg} / \mathrm{m}^{2}\right)$. Pada penelitian yang dilakukan oleh Budi Aristya pada tahun 2019 menunjukkan bahwa terdapat perbedaan yang signifikan antara kadar MDA pada dewasa muda obes dan non obes. Kadar MDA pada kelompok dewasa muda obes lebih tinggi dibandingkan dengan kelompok dewasa muda non obes. Karena itulah pada penelitian ini BMl termasuk dalam variabel kontrol untuk menghilangkan bias terhadap pengaruh dari BMI sampel. ${ }^{8}$

\section{Kadar MDA Serum Sebelum Olahraga pada Pagi dan Malam Hari}

Rerata kadar MDA serum sebelum olahraga pada pagi hari lebih rendah dibandingkan dengan rerata kadar MDA malam hari. Rerata kadar MDA sebelum olahraga pada pagi hari yaitu $2,73 \pm 0,75$ $\mathrm{nmol} / \mathrm{mL}$ sedangkan pada malam hari $3,03 \pm 0,78$ $\mathrm{nmol} / \mathrm{mL}$ (Gambar 1). Hasil analisis data menggunakan two sample independent t-test menunjukkan perbedaan antara kadar MDA serum sebelum olahraga pagi dan kadar MDA serum sebelum olahraga malam hari tidak signifikan $(p=0,254)$

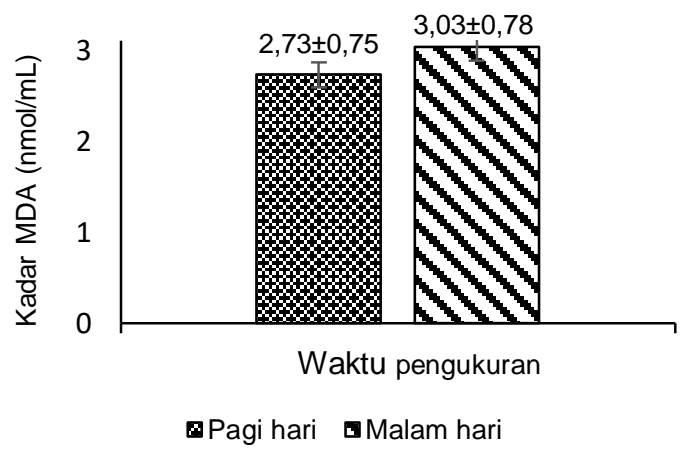

Gambar 1. Perbandingan kadar MDA sebelum olahraga pada pagi dan malam hari.

\section{Perbandingan Kadar MDA Sebelum dan Setelah Olahraga pada Pagi Hari}

Pengukuran kadar MDA sebelum (pre) dan setelah (post) olahraga pagi hari tidak menunjukkan adanya peningkatan yang signifikan. Peningkatan kadar MDA tersebut dapat dilihat pada Gambar 2. Rerata kadar MDA sebelum olahraga yaitu sebesar 2,73 $\pm 0,75 \mathrm{nmol} / \mathrm{mL}$ dan rerata kadar MDA sesudah berolahraga sebesar $3,02 \pm 0,75 \mathrm{nmol} / \mathrm{mL}$. Hasil uji $\mathrm{t}$ berpasangan menunjukkan perbedaan tersebut tidak signifikan $(p=0,157)$.

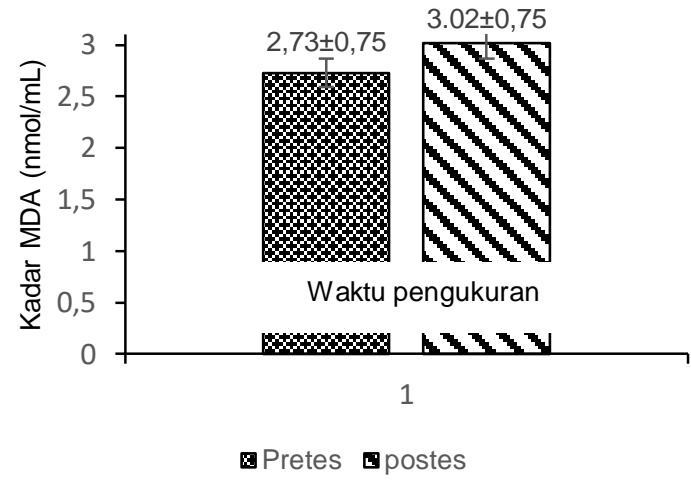

Gambar 2. Hasil pengukuran kadar MDA pre dan post olahraga pada pagi hari

\section{Perbandingan Kadar MDA Sebelum dan Setelah Olahraga pada Malam Hari}

Gambar 3 menunjukkan hasil pengukuran kadar MDA serum sebelum dan setelah olahraga pada malam hari. Kadar MDA serum sebelum olahraga pada malam hari rerata sebesar $3,03 \pm 0,78 \mathrm{nmol} / \mathrm{mL}$ dan setelah olahraga didapatkan rerata sebesar $4,17 \pm 1,17 \mathrm{nmol} / \mathrm{mL}$. Setelah dilakukan uji $\mathrm{t}$ berpasangan didapatkan hasil yang signifikan untuk peningkatan kadar MDA antara sebelum dan setelah olahraga malam hari $(p=0,01)$. Hal ini menunjukkan bahwa terdapat peningkatan kadar MDA setelah melakukan olahraga pada malam hari. 


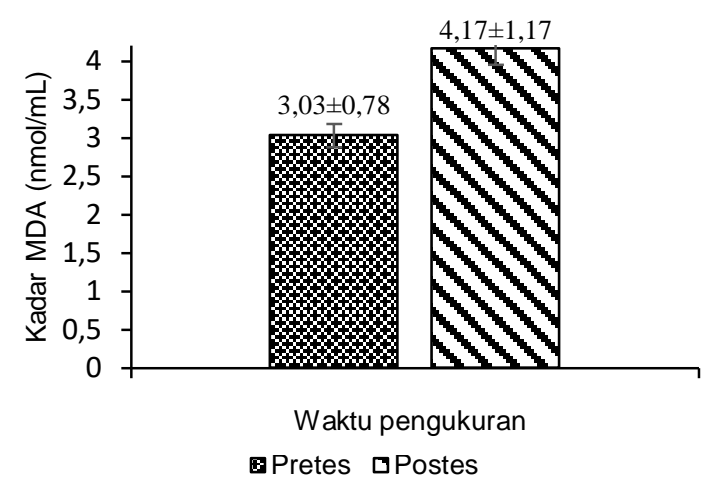

Gambar 3. Grafik perbandingan kadar MDA pre dan post olahraga pada malam hari

\section{Perbandingan Peningkatan Kadar MDA Sebelum dan Setelah Olahraga Pada pagi dan Malam Hari}

Gambar 4 menunjukkan rerata peningkatan kadar MDA setelah olahraga pagi hari adalah $0,29 \pm 0,87 \mathrm{nmol} / \mathrm{mL}$. Rerata peningkatan kadar MDA setelah olahraga malam hari memiliki selisih sebesar 0,826 lebih tinggi yaitu $1,13 \pm 1,26 \mathrm{nmol} / \mathrm{mL}$. Hasil uji two sample independent t-test yang dilakukan terhadap rerata peningkatan kadar MDA setelah olahraga pagi dan malam hari menunjukkan terdapat perbedaan signifikan antara rerata peningkatan kadar MDA setelah olahraga pagi hari dan malam hari $(p=0,021)$.

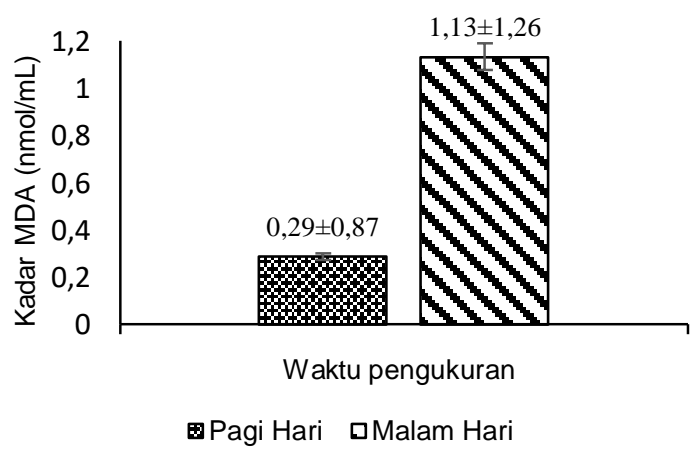

Gambar 4. Grafik perbandingan peningkatan kadar MDA setelah olahraga pagi dan malam hari

\section{PEMBAHASAN}

Hasil pada penelitian ini menunjukkan kadar MDA serum sebelum olahraga pada pagi hari tidak berbeda signifikan dengan kadar MDA pada malam hari, meskipun didapatkan rata-rata kadar MDA pagi hari lebih rendah dibandingkan kadar MDA malam hari. Malondialdehid (MDA) merupakan senyawa toksik yang dihasilkan dari proses peroksidasi lemak akibat aktivitas radikal bebas. Pada pagi hari kadar MDA relatif lebih rendah dikarenakan antioksidan bekerja optimal. Penelitian yang dilakukan oleh Fumero pada tahun 2018 menyebutkan bahwa kapasitas total antioksidan dalam tubuh lebih tinggi pada pagi hari dibandingkan dengan siang hari atau malam hari. $^{9}$ Penelitian lain yang dilakukan oleh Chakravarty dan Rizvi pada tahun 2011 menyebutkan terdapat perbedaan signifikan kadar melatonin pada pagi hari dan malam hari yang menyebabkan marker stres oksidatif seperti MDA juga mengalami perbedaan. ${ }^{10}$ Usia responden yang tergolong usia dewasa muda menyebabkan perbedaan yang tidak signifikan pada kadar MDA sebelum olahraga pada pagi dan malam hari. Usia muda memiliki kadar antioksidan lebih tinggi sehingga mampu menetralkan radikal bebas dalam tubuh. Penelitian sebelumnya menyebutkan bahwa kelompok usia yang lebih muda memiliki kadar antioksidan yang lebih tinggi. ${ }^{11}$

Hasil pengukuran kadar MDA sebelum dan setelah olahraga pada pagi hari menunjukkan tidak terdapat peningkatan, namun pada malam hari terdapat peningkatan yang signifikan. Hal ini diakibatkan karena adanya mekanisme tambahan saat olahraga pada malam hari yang menyebabkan kadar radikal bebas tubuh meningkat lebih tinggi. Olahraga merupakan stresor fisiologis yang mampu menginduksi produksi dari radikal bebas. Pada penelitian sebelumnya dengan menggunakan latihan berupa sepeda statis selama 10-90 menit terbukti mengakibatkan peningkatkan kadar MDA serum. ${ }^{12}$ Terdapat tiga teori yang menjelaskan kondisi tersebut. Pertama, saat olahraga terjadi peningkatan metabolisme sehingga terjadi peningkatan aktivitas dari mitokondria. Aktivitas mitokondria menghasilkan produk samping yaitu radikal bebas. Makin tinggi aktivitas mitokondria maka radikal bebas yang dihasilkan juga makin tinggi. Mekanisme kedua yaitu aktivitas dari NADPH dan xantin oksidase. Mekanisme ketiga terjadi melalui stimulasi akibat kerusakan sel yang menginduksi proses inflamasi dan aktivitas dari fagosit. Keseluruhan mekanisme tersebut menyebabkan peningkatan kadar radikal bebas dalam 
tubuh. Peningkatan kadar radikal bebas yang tidak mampu dinetralkan akan menyebabkan stres oksidatif yang ditandai dengan peningkatan kadar MDA. ${ }^{13}$

Kadar MDA sebelum dan setelah olahraga pada pagi hari tidak menunjukkan peningkatan yang signifikan. Hal ini terjadi karena olahraga selain mengakibatkan peningkatan kadar radikal bebas dalam tubuh juga menekan aktifitas prooksidan. ${ }^{14}$ Olahraga yang mampu menginduksi adanya radikal bebas yang berlebihan menyebabkan tubuh akan melakukan kompensasi dengan memproduksi antioksidan seperti glutathione dan superoxide dismutase (SOD). ${ }^{15}$ Usia relawan tergolong dalam remaja akhir sehingga proses metabolisme dalam tubuh masih bekerja dengan baik dalam menatrilisir radikal bebas saat melakukan olahraga. ${ }^{16}$

Olahraga pada malam hari memiliki mekanisme tambahan yang mampu meningkatkan jumlah radikal bebas dalam tubuh yang lebih besar sehingga tidak dapat dinetralkan seperti ketika olahraga pada pagi hari. Faktor yang lain, pada malam hari kadar oksigen dalam udara lebih sedikit dibandingkan pada pagi hari sehingga lebih mudah mengakibatkan hipoksia jika melakukan olahraga. Penelitian sebelumnya membuktikan bahwa kondisi hipoksia mampu menyebabkan peningkatan dari reactive oxygen species (ROS) dalam tubuh. Kondisi hipoksia menyebabkan terjadinya kerusakan dalam sel sehingga akan memicu proses inflamasi yang mengakibatkan peningkatan dari radikal bebas. ${ }^{17}$

Olahraga pada malam hari juga menyebabkan gangguan ritme sirkadian. Gangguan ritme sirkadian tersebut menyebabkan penurunan konsentrasi melatonin yang bekerja sebagai antioksidan. Penurunan konsentrasi melatonin dan aktivitasnya sebagai antioksidan tersebut menyebabkan peningkatan ROS di dalam sel. ${ }^{18}$ Dalam keadaan normal, orang dapat menahan stres oksidatif ringan dan mengembalikan keseimbangan redoks melalui sistem antioksidan alami yang disediakan tubuh. Namun, pertahanan antioksidan yang berlebihan akibat stres oksidatif parah seperti aktivitas olahraga yang tidak tepat dapat meningkatkan kerusakan sel. $^{19,20}$ Peningkatan ROS tersebut jika tidak mampu diimbangi dengan antioksidan akan menyebabkan terjadinya stres oksidatif. Kelebihan ROS tersebut akan bereaksi dengan berbagai komponen dalam tubuh seperti lemak, protein dan DNA. Jika ROS bereaksi dengan protein akan menyebabkan oksidasi protein dan jika bereaksi dengan DNA dapat menyebabkan mutasi DNA. ${ }^{20}$ Membran sel maupun membran organel banyak mengandung lemak yang memiliki rantai ganda sehingga lebih mudah bereaksi dengan ROS, selanjutnya menyebabkan reaksi berantai atau yang sering disebut peroksidasi lipid yang dapat menyebabkan kerusakan sel. ${ }^{21}$ Peroksidasi lipid tersebut akan menyebabkan rantai asam lemak terputus menjadi berbagai senyawa toksik, salah satunya yaitu malondialdehid (MDA). ${ }^{18,22}$

Peningkatan kadar MDA menandakan kondisi stres oksidatif. ${ }^{22}$ Stres oksidatif berperan penting terhadap patogenesis berbagai macam penyakit. Misalnya diabetes mellitus ${ }^{23}$ dengan komplikasinya ${ }^{24}$ dan keganasan ${ }^{22}$. Salah satu upaya untuk pencegahan terjadinya penyakit-penyakit tersebut adalah menghindari tubuh dari kondisi stres oksidatif. $^{22,23,24}$ Hasil penelitian ini membuktikan bahwa olahraga yang dilakuan pada malam hari lebih berisiko memicu stres oksidatif dibandingkan dengan olahraga yang dilakukan pada pagi hari.

\section{SIMPULAN}

Terdapat perbedaan yang signifikan antara kenaikan kadar MDA setelah olahraga pada pagi dan malam hari pada orang yang tidak terlatih. Peningkatan kadar MDA pada malam hari lebih tinggi dibandingkan dengan peningkatan pada pagi hari.

\section{DAFTAR PUSTAKA}

1. Kim HG, Kim YJ, Ahn YC, dan Son CG. Serum levels of stress hormones and oxidative stress biomarkers differ according to sasang constitutional type. Evidence-Based Complementary and Alternative Medicine [serial online]. 2015 Oktober (diunduh 13 Juli 2020). Tersedia dari: http://dx.doi.org/10.1155/2015/ 737631

2. Flaherty $R L$, Owen $M$, Fagan-Murphy $A$, Intabli $H$, Healy D, Patel A, Allen MC, Patel BA, dan Flint MS. Glucocorticoids induce production of reactive oxygen species/reactive nitrogen species and dna damage through an inos mediated pathway in 
breast cancer. Breast Cancer Research. 2017; 19(35):1-13.

3. Sen S, Chakraborty R, Sridhar C, Reddy YSR, dan De B. Free radicals, antioxidants, diseases and phytomedicines: current status and future prospect. International Journal of Pharmaceutical Sciences Review and Research. 2010;3(1):91-100.

4. Hacışevki A, Baba B. An overview of melatonin as an antioxidant molecule: a biochemical approach. Melatonin-Molecular Biology, Clinical and Pharmaceutical Approaches [serial online]. 2018 (diunduh 13 Juli 2020).Tersedia dari: https://www. researchgate.net/publication/329139329

5. Spirlandeli A, Rafael D, Alceu J. Plasma Malondialdehyde as Biomarker of Lipid Peroxidation: Effects of Acute Exercise. International journal of sports medicine. 2014; 35:14-8.

6. Riebe D, Jonathan EK, Liguori G, Magal M. General principles of exercise prescription. In: ACSM's Guidelines for Exercise Testing and Prescription. 10th Ed. Philadelphia: Wolters Kluwer/Lippincott Williams \& Wilkins; 2018.

7. Liguori I, Russo G, Curcio F, Bulli G, Aran L, Della-Morte D, Gargiulo G, Testa G, Cacciatore F, Bonaduce D, Abete P. Oxidative stress, aging, and diseases. Clinical Interventions in Aging 2018; 13:757-72.

8. Aristya B, Kadri H, Asri A. Perbedaan kadar malondialdehid pada dewasa muda obes dan nonobes di fakultas kedokteran Universitas Andalas. Jurnal Kesehatan Andalas. 2019; 8 (supll 2): 21-5.

9. Fumero ALM, Gonzalez PA, Benitez MH, Lopez LF, Mesa ED, Mendez MDRC, et al. Day/night and summer/winter changes in serum total antioxidant capacity. Medicinal Chemistr. 2018; 14(3):225-9.

10. Chakravarty S, Rizvi SI. Day and Night GSH and MDA Levels in Healthy Adults and Effects of Different Doses of Melatonin on These Parameters. Int J Cell Biol [serial online]. 2011 April (diunduh 13 Juli 2020). Tersedia dari: https://www.researchgate.net/publication/51197399

11. Bouzid MA, Filaire E, Matran R, Robin S, Fabre C. Lifelong Voluntary Exercise Modulates AgeRelated Changes in Oxidative Stress. Int J Sports Med. 2018;39(01):21-8.
12. Kawamura T, Muraoka I. Exercise-induced oxidative stress and the effects of antioxidant intake from a physiological viewpoint. Antioxidants. 2018; 7(9):119-26.

13. Powers SK, Radak Z, Ji LL. Exercise-induced oxidative stress: past, present and future. The Journal of Physiology. 2016; 594(18):5081-92.

14. Skishahr FS, Damirchi A, Farjaminezhad $M$, Babaei P. Physical training status determines oxidative stress and redox changes in response to an acute aerobic exercise. Biochem Res Int. 2016; 2016(4):1-9.

15. De Sousa CV, Sales MM, Rosa TS, Lewis JE, de Andrade RV, Simões HG. The antioxidant effect of exercise: a systematic review and meta-analysis. Sports Medicine. 2017; 47(2):277-93.

16. Woźniak EH, Szymańska JO, Stupnicki R, Malara M, Kozdroń E. Age-related blood antioxidant capacity in men and women. Journal of Medical Biochemistry. 2011; 30(2):103-8.

17. Cheng DL, Zhu N, Li, CL Lu WF, Fang WW, Liu Y, Li CT. Significance of malondialdehyde, superoxide dismutase and endotoxin levels in budd-chiari syndrome in patients and a rat model. Experimental and Therapeutic Medicine. 2018; 16(6):5227-35.

18. Yunus M. Pengaruh akvitas badminton pada malam hari terhadap stres oksidatif (studi kasus pada mahasiswa Universitas Negeri Malang). Jurnal Kepelatihan Olahrahga 2016; 1(1): 1-5.

19. Urso ML, Clarkson PM. Oxidative stress, exercise, and antioxidant supplementation. Toxicology. 2003;189((2):41-54.

20. Fang $Y Z$, Yang $S$, Wu G. Free radicals, antioxidants, and nutrition. Nutrition (2002; 18(10):872-9.

21. Ferrelli F, Pastore D, Capuani D, Lombardo MF, Blotchabaut M, Coppola A, et al. Serum glucocorticoid inducible kinase (SGK)-1 protects endothelial cells against oxidative stress and apoptosis induced by hyperglycaemia. Acta Diabetologica. 2015; 52(1):55-64.

22. Zapf I, Moezzi M, Fekecs T, Nedvig K, De'nes Lorinczy D, Ferencz A. Influence of oxidative injury and monitoring of blood plasma by DSC on breast 
cancer patients. J Therm Anal Calorim. 2016; (123):2029-35.

23. Pesta D, Roden M. The janus head of oxidative stress in metabolic diseases and during physical exercise. Curr Diab Rep. 2017;17(41):1-13.
24. Klisic A, Kocic G, Kavaric N, Jovanovic M, Stanisic V, Ninic A. Xanthine oxidase and uric acid as independent predictors of albuminuria in patients with diabetes mellitus type 2. Clinical and Experimental Medicine. 2018;18: 283-90. 